\title{
Perlindungan Hukum Bagi Kreditor Dalam Kaitannya Dengan Permohonan Pailit Yang Diajukan Oleh Debitor \\ Studi Kasus Pada PT. BANK CIMB NIAGA Melawan PT. Sumatera Persada Energi
}

\author{
Oleh : \\ Imam Magribi, Dewi Tuti Muryati, Supriyadi \\ Fakultas Hukum Universitas Semarang \\ imam_magribi@gmail.com,dewi_tuti@yahoo.com,supriyadi@gmail.com
}

\begin{abstract}
ABSTRAK
Tindakan Pailit adalah suatu sitaan umum atas semua kekayaan Debitor Pailit yang pengurusan dan pemberesannya dilakukan oleh Kurator dibawah pengawasan Hakim Pengawas. Harta pailit akan dibagikan sesuai dengan porsi besarnya tuntutan Kreditor. Berdasarkan latar belakang maka yang menjadi pokok permasalahan dari penelitian ini adalah bagaimana perlindungan hukum kreditor atas kepailitan yang diajukan debitor, dan bagaimana penyelesaian harta pailit debitor kepada para kreditor sehubungan dengan permohonan pailit oleh debitor. Penelitian hukum dengan tipe penelitian menggunakan yuridis normatif, spesifikasi penelitian deskriptif analitis, metode pengumpulan data menggunakan data sekunder yang meliputi bahan hukum primer, bahan hukum sekunder, dan bahan hukum tersier, metode analisis datanya menggunakan analisis kualitatif. Perlindungan hukum kreditor atas kepailitan yang diajukan debitor atas permohonan kepailitan yang dilakukan oleh PT. Sumatera Persada Energi telah sesuai dengan Undang-Undang Kepailitan yang berlaku baik Undang-Undang Nomor 4 Tahun 1998 maupun UUKPKPU, karena secara substansial tidak ada perubahan dalam syarat-syarat pengajuan permohonan kepailitan. Syarat-syarat pengajuan permohonan kepailitan tersebut jauh dari asas keadilan bagi penyelesaian kepailitan antara debitor dan kreditor, terutama bagi kreditor yang mempunyai debitor harta kekayaannya (boedel) tidak cukup untuk membayar keseluruhan hutang kepada kreditor.
\end{abstract}

Kata Kunci : Perlindungan Hukum; Pailit; Debitor; Kreditor;

\begin{abstract}
The Bankruptcy Act is a public confiscation of all the wealth of the Bankrupt Debtor whose stewardship and ordering are carried out by the Curator under the supervision of the Supervisory Judge. Bankruptcy assets will be distributed in accordance with the portion of the creditors demand. Based on the background then the subject matter of this research is how the protection of the creditors law on bankruptcy filed debtor, and how the debtor bankruptcy property settlement to the creditors in connection with the request for bankruptcy by the debtor. Research method, research method consist of type / type of research using normative juridical, research specification using analytical descriptive, data collection method using secondary data covering primary law material, secondary law material, and tertiary law material, method of data analysis using qualitative analysis. Protection of the creditor's law of bankruptcy filed by the debtor on the Bankruptcy Application made by PT. Sumatra Persada Energi has been in compliance with the Bankruptcy Act applicable both Law Number 4 of 1998 and UUKPKPU, because substantially there is no change in the requirements for filing of bankruptcy petition. The requirements for filing a petition for bankruptcy are far from the principle of justice for bankruptcy settlement between the debtor and the creditor, especially for creditors whose debtor is not enough to pay the entire debt to the creditors.
\end{abstract}

Keywords : Legal Protection; Bankruptcy; Creditor; Debtor;. 


\section{PENDAHULUAN}

\section{A. Latar Belakang Penelitian}

Realisasi dan tindakan pemerintah untuk melindungi hak-hak pihak yang berkaitan dengan masalah kepailitan adalah merevisi Undang-Undang Kepailitan sebagaimana diatur dalam Staatsblaad Tahun 1905 Nomor 217 juncto Staatsblaad Tahun 1906 Nomor 348 menjadi Peraturan Pemerintah Pengganti Undang-Undang ( Perpu ) Nomor 1 Tahun 1998 tentang Perubahan Atas Undang-Undang Kepailitan yang dikeluarkan pada tanggal 22 April 1998. Tanggal 9 September 1998 Perpu Nomor 1 Tahun 1998 disahkan menjadi Undang-Undang Nomor 4 Tahun 1998 tentang Perubahan Atas Undang-Undang Kepailitan menjadi Undang-Undang, akhirnya pada tanggal 18 Oktober 2004 Undang-Undang Nomor 4 Tahun 1998 diganti menjadi Undang-Undang Nomor 37 Tahun 2004 tentang Kepailitan Dan Penundaan Kewajiban Pembayaran Utang.

Pengantian Undang-Undang Nomor 4 Tahun 1998 menjadi Undang-Undang Nomor 37 Tahun 2004 sangat penting, karena sudah dianggap tidak sesuai lagi dengan perkembangan jaman. Sebagai pengemban amanat rakyat, presiden mempunyai kewajiban konstitusional untuk melaksanakan pembangunan nasional, salah satu bagian dari pembangunan nasional adalah pembangunan hukum nasional yang berorientasi kepada mewujudkan masyarakat adil dan makmur berdasarkan pancasila dan UUD 1945. Salah satu produk hukum yang bertujuan untuk menjamin kepastian, ketertiban, penegakan dan perlindungan hukum yang berisi keadilan dan kebenaran yang diperlukan saat ini guna mendukung pembangunan perekonomian nasional adalah peraturan mengenai kepailitan dan penundaan kewajiban pembayaran utang. 1

Permohonan pailit pada dasarnya merupakan suatu permohonan yang diajukan ke Pengadilan Niaga oleh pihak-pihak tertentu atau penasehat hukumnya karena suatu hal tidak dapat membayar hutang-hutangnya kepada pihak lain. Pihak-pihak yang dapat mengajukan permohonan pailit adalah debitor, kreditor, Kejaksaan untuk kepentingan umum, Bank Indonesia yang menyangkut debitornya adalah bank, Badan Pengawas Pasar Modal yang debitornya merupakan perusahaan efek, dan Menteri Keuangan yang debitornya Perusahaan Asuransi, Perusahaan Reasuransi, Dana Pensiun, atau Badan Usaha Milik Negara yang bergerak di bidang kepentingan publik, beserta OJK yang sekarang mempunyai wewenang dalam mengatasi hal tersebut.

Menurut Henry Campbell Black, bangkrut atau pailit adalah seorang pedagang yang bersembunyi atau melakukan tindakan tertentu yang cenderung untuk mengelabui pihak kreditornya. Dalam hal seperti ini hak-hak sebagai kreditor tidak terlindungi terhadap debitor yang mempunyai itikad tidak baik. Seperti halnya yang terjadi dalam Pengadilan Niaga terdapat praktek-praktek yang menyebabkan lembaga kepailitan tidak berjalan dengan semestinya, Pengadilan Niaga telah digunakan untuk melegitimasi praktek-praktek tidak membayar utang atau praktek utang yang diabayar menurut kehendak si debitor. ${ }^{2}$

1 Budisastra, Aspek Hukum Dalam Kepailitan, ( http :// budisastra. info/ home, 2009/ baca /.pdf /, diunduh 30 Mei 2016 ), halaman 19. 
Hal ini serupa terjadi pada kasus kepailitan antara kreditor PT. SPE, yaitu Bank CIMB Niaga melawan PT. Sumatera Persada Energi ( SPE ) sebagai debitor. PT. SPE adalah salah satu contoh masalah kepailitan, akibatnya pemesanan barang mengalami penurunan dan biaya operasional yang dikeluarkan tidak sebanding dengan hasil penjualan produksi. Dengan keadaan itu para karyawan mengundurkan diri secara bertahap karena mengetahui keuangan perusahan sedang tidak baik, disusul dengan adanya pemutusan hubungan kerja karyawan sehingga tinggal beberapa karyawan honorer untuk mengurus administrasi perusahaan.

Selama menjalankan perusahaannya, PT.Sumatera Persada Energi mempunyai hutang kepada PT. Bank CIMB Niaga sebesar USD 20,36 juta. Pada kenyataannya sampai sekarang hutang tersebut belum terbayar dan yang lebih mengejutkan hutang tersebut melebihi aset-aset perusahaan yang hanya bernilai Rp 23,7 miliar.

PT.Sumatera Persada Energi setelah mengadakan Rapat Umum Pemegang Saham selanjutnya mengajukan permohonan pernyataan pailit terhadap dirinya sendiri pada tanggal 11 Oktober 2014, akhirnya pada tanggal 26 Oktober 2014 dalam rapat permusyawaratan Majelis Hakim dengan susunan : Titiek Tedjaningsih, S.H. sebagai Hakim Ketua Majelis, Sudrajad Dimyati, S.H., putusan mana diucapkan pada tanggal 2 September 2014 dalam sidang yang terbuka untuk umum memutuskan mengabulkan permohonan Pemohon pailit yaitu PT. Sumatera Persada Energi berada dalam keadaan pailit, dengan segala akibat hukumnya.

Dengan adanya putusan pailit dari Pengadilan Niaga Jakarta Pusat terhadap PT.Sumatera Persada Energi, PT. Bank CIMB Niaga, Tbk selaku salah satu kreditornya mengajukan Kasasi ke Mahkamah Agung untuk membatalkan putusan pailit tersebut, tetapi pada tanggal 7 Desember 2014 dalam rapat permusyawaratan Mahkamah Agung menyatakan bahwa permohonan kasasi dari Pemohon Kasasi PT.Bank CIMB Niaga, Tbk tersebut tidak dapat diterima.

Merasa permohonan kasasi tersebut tidak dapat diterima oleh Mahkamah Agung maka PT.Bank CIMB Niaga,Tbk mengajukan upaya hukum terakhir melalui Peninjauan Kembali ke Mahkamah Agung berharap agar putusan pailit terhadap PT.Sumatera Persada Energi dapat dibatalkan, tetapi berdasarkan rapat permusyawaratan Mahkamah Agung tanggal 28 Maret 2015 menyatakan bahwa permohonan peninjauan kembali dari Pemohon Kasasi PT. Bank CIMB Niaga,Tbk tersebut tidak dapat diterima.

\section{B. Perumusan Masalah}

1. Bagaimana perlindungan hukum kreditor atas kepailitan yang diajukan debitor?

2. Bagaimana penyelesaian harta pailit debitor kepada para kreditor sehubungan dengan permohonan pailit oleh debitor? 


\section{Tujuan Dan Manfaat Penelitian}

a) Tujuan utama yang hendak dicapai penelitian ini adalah sebagai berikut :

1. Untuk mengetahui dan menganalisis perlindungan hukum kreditor atas kepailitan yang diajukan debitor.

2. Untuk mengetahui dan menganalisis penyelesaian harta pailit debitor kepada para kreditor sehubungan dengan permohonan pailit oleh debitor.

b) Kegunaan dan manfaat penelitian.

1. Kegunaan Teoritik :

a. Dapat memberikan sumbangan dan masukan pemikiran di bidang ilmu pengetahuan hukum, khususnya hukum kepailitan.

b. Penelitian ini diharapkan dapat menambah wawasan dan khasanah pengetahuan di bidang hukum khususnya hukum kepailitan tentang perlindungan hak-hak kreditor dalam kepailitan.

2. Kegunaan Praktis :

a. Bagi Mahasiswa, sebagai masukan dan referensi kepada mahasiswa baik secara Hukum Perdata Khususnya Hukum Kepailitan.

b. Memberikan sumbangan pemikiran kepada kalangan Akademisi Kampus, praktisi hukum bisnis, Lembaga Pemerintah, Institusi Peradilan termasuk Aparatur Penegak Hukum lainnya dalam rangka menerapkan dan menegakkan Undang-Undang Kepailitan maupun Peraturan Perundang-undangan lainnya yang memiliki relevansi dengan hukum bisnis di Indonesia yang bertujuan memberikan perlindungan hukum terhadap kepentingan publik.

\section{TINJAUAN PUSTAKA}

\section{A. Tinjauan Tentang Kepailitan}

Pemerintah melakukan penyempurnaan terhadap peraturan hukum kepailitan dengan mengeluarkan Peraturan Pemerintah Pengganti Undang-Undang Nomor 1 Tahun 1998 Tentang Perubahan Atas Undang-Undang Tentang Kepailitan, yang diundangkan pada tanggal 22 April 1998 melalui Lembaran Negara Indonesia Nomor 87 Tahun 1998 dan berlaku efektif 120 hari sejak tanggal diundangkannya yaitu pada tanggal 20 Agustus 1998, setelah diterima oleh Dewan Perwakilan Rakyat kemudian menjadi Undang-Undang Nomor 4 tahun 1998. Dengan berlakunya Undang-Undang Nomor 4 tahun 1998 ini berarti pemerintah telah memenuhi salah satu persyaratan yang diminta oleh kreditor-kreditor luar negeri ( baca Dana Moneter Internasional / International Monetary Fund ), agar para kreditor luar negeri memperoleh jaminan kepastian hukum. ${ }^{3}$ 
Mengingat Undang-Undang Nomor 4 Tahun 1998 banyak kekurangan dan perlu adanya penambahan materi, maka pada tanggal 18 Oktober 2004 Dewan Perwakilan Rakyat mengesahkan Undang-Undang baru yang mengatur tentang kepailitan dan penundaan kewajiban pembayaran utang yaitu Undang-Undang Nomor 37 Tahun 2004. Muatan materi yang tercantum dalam UUKPKPU ( Undang-Undang Kepailitan Dan Penundaan Kewajiban Pembayaran Utang ) terdiri dari tujuh bab yaitu Bab I Ketentuan Umum, Bab II Kepailitan, Bab III Penundaan Kewajiban Pembayaran Utang, Bab IV Permohonan Penunjauan Kembali, Bab V Ketentuan lain-lain, Bab VI Ketentuan Peralihan, Bab VII Ketentuan Penutup. Asas-Asas Hukum Kepailitan antara lain :

1) Asas Keseimbangan : Undang-Undang ini mengatur beberapa ketentuan yang merupakan perwujudan dari asas keseimbangan, yaitu di satu pihak, terdapat ketentuan yang dapat mencegah terjadinya penyalahgunaan pranata dan lembaga kepailitan oleh debitor yang tidak jujur, di lain pihak terdapat ketentuan yang dapat mencegah terjadinya penyalahgunaan pranata dan lembaga kepailitan oleh kreditor yang tidak beritikad baik.

2) Asas Kelangsungan Usaha : Dalam Undang-Undang ini, terdapat ketentuan yang memungkinkan perusahaan debitor yang prospektif tetap dilangsungkan.

3) Asas Keadilan : Dalam kepailitan asas keadilan mengandung pengertian, bahwa ketentuan mengenai kepailitan dapat memenuhi rasa keadilan bagi para pihak yang berkepentingan. Asas keadilan ini untuk mencegah terjadinya kesewenang-sewenangan pihak penagih yang mengusahakan pembayaran atas tagihan masing-masing terhadap debitor, dengan tidak mempedulikan kreditor lainnya.

4) Asas Integrasi : dalam Undang-Undang ini mengandung pengertian bahwa sistem hukum formil dan hukum materiilnya merupakan satu kesatuan yang utuh dari sistem hukum perdata dan hukum acara perdata nasional.

Ketentuan kepailitan bertujuan untuk melakukan pembagian kekayaan milik debitor kepada para kreditornya dengan melakukan sitaan bersama dan kekayaan debitor dapat dibagikan kepada kreditor sesuai dengan haknya. Berkaitan dengan ini berlaku ketentuan Pasal 1131 dan Pasal 1132 Kitab Undang-Undang Hukum Perdata yang mengatur dan memberikan kedudukan para kreditor sebagai kreditor konkuren sehingga boedel pailit akan dibagikan kepada para kreditor secara seimbang ( ponds gewijs/paritas creditorium ), kecuali apabila diberikan perkecualian oleh UndangUndang, yaitu sebagaimana tertera dalam Pasal 1131 dan Pasal 1132 KUH Perdata. ${ }^{4}$

Mengutip pendapat Siti Soemarti Hartono, kepailitan adalah suatu lembaga hukum perdata Eropa sebagai asas realisasi dari dua asas pokok dalam hukum perdata Eropa yang tercantum dalam Pasal 1131 dan 1132 KUH Perdata. Adanya lembaga kepailitan berfungsi untuk mencegah kesewenang-wenangan pihak kreditor yang memaksa dengan berbagai cara agar debitor membayar utangnya.

${ }^{4}$ Retnowulan Sutantio, Kapita Selekta Hukum Ekonomi Dan Perbankan, Ctk. Pertama, ( Jakarta : Varia Yustisia, 2007 ), halaman 85. 


\section{B. Syarat Pengajuan pailit}

Dalam Undang-Undang Kepailitan, pengaturan tentang syarat kepailitan diatur lebih tegas, hal ini semata-mata untuk menghindari adanya :

1. Perebutan harta debitor apabila dalam waktu yang sama ada beberapa kreditor yang menagih piutangnya dari debitor.

2. Kreditor pemegang hak jaminan kebendaan yang menuntut haknya dengan cara menjual barang milik debitor tanpa memperhatikan kepentingan debitor atau para kreditor lainnya.

3. Kecurangan-kecurangan yang dilakukan oleh salah seorang kreditor atau debitor sendiri. Misalnya, debitor berusaha untuk memberi keuntungan kepada seorang atau beberapa orang kreditor tertentu sehingga kreditor lainnya dirugikan, atau adanya perbuatan curang dari debitor untuk melarikan semua harta kekayaannya dengan maksud untuk melepaskan tanggung jawabnya terhadap para kreditor.

Yang dapat menjadi pemohon dalam suatu perkara pailit adalah suatu pihak sebagai berikut:

1. pihak debitor itu sendiri ;

2. salah satu atau lebih dari pihak kreditor ;

3. pihak Kejaksaan jika menyangkut dengan kepentingan umum ;

4. pihak Bank Indonesia jika debitornya adalah suatu bank ;

5. pihak Badan Pengawas Pasar Modal jika debitornya adalah suatu perusahaan efek, bursa efek, lembaga kliring dan penjamin, lembaga penyimpanan dan penyelesaian ;

6. pihak Menteri Keuangan jika debitornya adalah perusahaaan asuransi, perusahaan reasuransi, dana pensiun, atau Badan Usaha Milik negara yang bergerak di bidang kepentingan publik.

\section{Akibat Hukum Pernyataan Kepailitan}

Dengan adanya putusan pailit oleh pengadilan, si pailit masih diperkenankan untuk melakukan perbuatan-perbuatan hukum dibidang harta kekayaan apabila dengan perbuatan hukum itu akan memberi keuntungan bagi harta kekayaan si Pailit, sebaliknya apabila dengan perbuatan hukum itu justru akan merugikan harta kekayaan si Pailit maka kerugian itu tidak mengikat harta kekayaan tersebut. $^{7}$

Putusan pailit oleh pengadilan tidak mengakibatkan Debitor kehilangan kecakapannya untuk melakukan perbuatan hukum ( volkomen handelingsbevoegd) pada umumnya, tetapi hanya kehilangan kekuasaan atau kewenangannya untuk mengurus dan mengalihkan harta kekayaannya saja, Debitor tidaklah berada di bawah pengampuan, tidak kehilangan kemampuannya untuk melakukan perbuatan hukum yang menyangkut dirinya kecuali apabila menyangkut pengurusan dan pengalihan harta bendanya yang telah ada. Tindakan pengurusan dan pengalihan tersebut berada pada Kurator. Apabila menyangkut harta benda yang akan diperolehnya Debitor tetap dapat melakukan perbuatan 
6 Pasal 2 Undang-Undang Nomor 37 Tahun 2004 tentang Kepailitan dan Penundaan Kewajiban Pembayaran Utang.

7 Zainal Asikin, Hukum Kepailitan dan Penundaan Pembayaran di Indonesia, ( Jakarta : PT. Raja Grafindo Persada, 2010 ), halaman 45-46. 
hukum menerima harta benda yang akan diperolehnya itu, namun harta yang diperolehnya itu kemudian menjadi bagian dari harta pailit. 8

Kepailitan meliputi seluruh kekayaan Debitor pada saat putusan pernyataan pailit diucapkan serta segala sesuatu yang diperoleh selama kepailitan ( Pasal 21 ). Namun dalam ketentuan tersebut tidak berlaku terhadap ketentuan berikut : 9

1. Benda, termasuk hewan yang benar-benar dibutuhkan oleh Debitor sehubungan dengan pekerjaannya, perlengkapannya, alat-alat medis yang dipergunakan untuk kesehatan, tempat tidur dan perlengkapannya yang dipergunakan oleh Debitor dan keluarganya, dan bahan makanan untuk 30 ( tiga puluh ) hari bagi Debitor dan keluarganya, yang terdapat di tempat itu ;

2. Segala sesuatu yang diperoleh Debitor dari pekerjaannya sendiri sebagai penggajian dari suatu jabatan atau jasa, sebagai upah, pensiun, uang tunggu atau uang tunjangan,

sejauh yang ditentukan oleh Hakim Pengawas ; atau

3. Uang yang diberikan kepada Debitor untuk memenuhi suatu kewajiban memberi nafkah menurut Undang-Undang.

Akibat pernyataan pailit bagi kreditor adalah kedudukan para kreditor sama ( paritas creditorium ) dan karenanya mereka mempunyai hak yang sama atas hasil eksekusi boedel pailit sesuai dengan besarnya tagihan mereka masing-masing ( paripassu pro rata parte ). Namun demikian asas tersebut mengenal pengecualian, yaitu golongan kreditor yang haknya didahulukan ( kreditor Separatis ) berdasarkan Undang-Undang Nomor 37 Tahun 2004 tentang Kepailitan PKPU dan peraturan perundangundangan lainnya ( Pasal 1139 dan Pasal 1149 KUH Perdata ). 10

\section{Upaya Hukum Dalam Kepailitan}

Setelah Pengadilan Niaga menjatuhkan putusan atas permohonan pernyataan pailit, maka upaya hukum yang dapat diajukan terhadap putusan tersebut adalah kasasi ke Mahkamah Agung ( Pasal 11 ayat (1) UUKPKPU ). Upaya hukum yang berupa kasasi ini diatur dalam Pasal 11 sampai dengan Pasal 13 UUKPKPU, yang prosesnya dapat dijelaskan sebagai berikut :

a) Pihak yang dapat mengajukan kasasiatas putusan pernyataan pailit.

Pihak yang dapat mengajukan kasasi atas putusan pernyataan pailit dapat dilihat dari Pasal 11 ayat (3) UUKPKPU, yang bunyinya : Permohonan kasasi sebagaimana dimaksud pada ayat (2), selain dapat diajukan oleh Debitor dan Kreditor yang merupakan pihak pada persidangan tingkat pertama, juga dapat diajukan oleh Kreditor lain yang bukan merupakan pihak pada persidangan tingkat pertama yang tidak puas terhadap putusan atas permohonan pernyataan pailit. 11

b) Tahap pendaftaran atas kasasi putusan pernyataan pailit.

Permohonan kasasi atas putusan pernyataan pailit diajukan paling lambat 8 hari setelah tanggal putusan yang dimohonkan kasasi diucapkan, dengan mendaftarkan kepada panitera Pengadilan Niaga

8 Sutan Remy Sjahdeini, Hukum Kepailitan Memahami Faillis sementsver ordening Juncto UndangUndang Nomor

4 Tahun 1998, ( Jakarta : Pustaka Grafiti, 2012 ), halaman 256-257. 
9 Pasal 22Ayat (1) Undang-Undang Nomor 37 Tahun 2004.

yang telah memutus permohonan pernyataan pailit tersebut. Panitera mendaftarkan permohonan kasasi pada tanggal permohonan yang bersangkutan diajukan dan kepada pemohon diberikan tanda terima tertulis yang ditandatangani panitera dengan tanggal yang sama dengan tanggal penerimaan pendaftaran.

c) Tahap persidangan atas kasasi putusan pernyataan pailit

MA wajib mempelajari permohonan kasasi dan menetapkan hari persidangan paling lambat 2 hari setelah tanggal permohonan kasasi diterima oleh MA. Sidang pemeriksaan atas permohonan tersebut dilakukan paling lambat 20 hari setelah tanggal permohonan kasasi diterima oleh MA.

d) Tahap putusan kasasi atas putusan pernyataan pailit

Putusan atas permohonan kasasi harus diucapkan paling lambat 60 hari setelah tanggal permohonan kasasi diterima oleh MA. Putusan MA tersebut yang memuat secara lengkap pertimbangan hukum yang mendasari putusan tersebut harus diucapkan dalam sidang terbuka untuk umum. Dalam hal terdapat perbedaan pendapat, hal tersebut wajib dimuat dalam putusan kasasi. Panitera MA wajib menyampaikan salainan putusan kasasi kepada panitera Pengadilan Niaga paling lambat 3 hari setelah tanggal putusan atas permohonan kasasi diucapkan.

\section{METODE PENELITIAN}

a) Jenis / Tipe Penelitian

Jenis / Tipe penelitian ini adalah penelitian hukum normatif, yaitu penelitian hukum yang dilakukan dengan cara meneliti bahan pustaka atau data sekunder belaka, dapat dinamakan penelitian hukum normatif atau penelitian hukum kepustakaan, penelitian tersebut mencakup :

1. Penelitian terhadap asas-asas hukum.

2. Penelitian terhadap sistematik hukum.

3. Penelitian terhadap taraf sinkronisasi vertikal dan horisontal.

4. Perbandingan hukum.

5. Sejarah hukum. 12

Dari kelima penelitian hukum normatif diatas, metode yang digunakan dalam penelitian ini adalah Penelitian terhadap taraf sinkronisasi vertikal dan horisontal yang bertujuan untuk sampai sejauh manakah hukum positif tertulis yang ada serasi, maka yang ditinjau adalah perundangundangan yang sederajat yang mengatur bidang yang sama. 13

b) Spesifikasi Penelitian

Spesifikasi penelitian yang akan digunakan adalah deskriptif analitis, metode ini bertujuan untuk memberikan gambaran dan deskripsi serta data yang seteliti mungkin mengenai perkara 
12 Soekanto Soerjono dan Sri Mamudji, Penelitian Hukum Normatif Suatu Tujuan Singkat, (

Jakarta : Raja Grafindo Persada, 2007 ), halaman 14.

permohonan pailit yang diajukan debitur dalam proses kepailitan. Analisa juga dilakukan dengan menggunakan cara kualitatif dari teori hukum atau doktrin-doktrin hukum terhadap perkara permohonan pailit yang diajukan debitur dalam proses kepailitan.

c) Metode Pengumpulan Data

Pengumpulan data mempunyai hubungan erat dengan sumber data, karena dengan pengumpulan data akan diperoleh data yang diperlukan untuk selanjutnya dianalisis sesuai kehendak yang diharapkan. Berkaitan dengan hal tersebut, dalam penelitian ini penulis menggunakan metode pengumpulan data kepustakaan. Data Sekunder diperoleh melalui studi pustaka atau literatur, Data sekunder tersebut meliputi :

1. Bahan Hukum Primer, yang merupakan bahan hukum yang mengikat berupa peraturan perundang-undangan dan putusan pengadilan,

2. Bahan hukum sekunder, merupakan bahan hukum yang memberikan penjelasan mengenai bahan hukum primer sebagaimana yang terdapat dalam kumpulan pustaka yang bersifat sebagai penunjang dari bahan hukum primer,

3. Bahan hukum tersier, merupakan bahan hukum yang memberikan petunjuk maupun penjelasan terhadap bahan hukum primer dan bahan hukum sekunder, yang berupa ; Kamus Hukum Belanda-Indonesia.

d) Metode Analisis Data

Metode yang digunakan dalam menganalisis dan mengolah data-data yang terkumpul adalah analisis kualitatif. Maksud dari penggunaan metode tersebut adalah memberikan gambaran terhadap permasalahan yang ada dengan berdasarkan pada pendekatan yuridis normatif. Pada metode ini datadata yang diperoleh yaitu data sekunder, akan diinventarisasi dan disistematiskan dalam uraian yang bersifat deskriptif analisis. Setelah dilakukan proses inventarisasi dan penyusunan data secara sistematis maka langkah selanjutnya ialah menganalisa data-data tersebut.

\section{HASIL PENELITIAN DAN PEMBAHASAN}

\section{A. Perlindungan Hukum Kreditor Atas Kepailitan Yang Diajukan Debitor}

Realisasi dan tindakan pemerintah untuk melindungi hak-hak pihak yang berkaitan dengan masalah kepailitan adalah menciptakan peraturan perundang-undangan tentang kepailitan yaitu Undang-Undang Nomor 37 Tahun 2004 tentang Kepailitan dan Penundaan Kewajiban Pembayaran Utang (PKPU). Kehadiran Undang-Undang Kepailitan dan Penundaan Kewajiban Pembayaran Utang (UUKPKPU) tersebut ditengah masyarakat khususnya para pelaku bisnis yang sedang menghadapi masalah sengketa utang piutang diharapkan dapat membantu penyelesaiannya, karena sistem yang digunakan sangat cepat, adil, terbuka, dan efektif serta menjadi pegangan bagi penyelesaian utang- 
piutang yang tidak saling merugikan melainkan sebaliknya justru saling menguntungkan para Kreditor dan

Debitor. 
Pailit dalam khasanah ilmu pengetahuan hukum diartikan sebagai keadaan debitor yang berutang yang berhenti membayar atau tidak membayar utang-utangnya, hal ini tercermin dalam Pasal 2 ayat (1) UUKPKPU yang menentukan bahwa : " Debitor yang mempunyai dua atau lebih kreditor dan tidak membayar lunas sedikitnya satu utang yang telah jatuh waktu dan dapat ditagih, dinyatakan pailit dengan putusan pengadilan, baik atas permohonannya sendiri maupun atas permohonan satu atau lebih kreditornya ".

Menurut Pasal 2 ayat (1) UUKPKPU tersebut permohonan pernyataan pailit terhadap seorang debitor dapat diajukan oleh debitor sendiri. Dalam istilah bahasa Inggris disebut voluntary petition, kemungkinan tersebut menurut Undang-Undang Kepailitan bukan saja untuk kepentingan kreditornya, tetapi dapat pula diajukan untuk kepentingan debitor sendiri. Debitor dapat mengajukan permohonan pailit terhadap dirinya hanya apabila terpenuhi syarat-syarat sebagai berikut :

1. Debitor mempunyai dua atau lebih kreditor, dan

2. Debitor sedikitnya tidak membayar satu utang yang telah jatuhwaktu dan telah dapat ditagih.

Ketentuan bahwa debitor dapat mengajukan permohonan pernyataan pailit terhadap dirinya sendiri adalah ketentuan yang dianut di banyak negara, maka hal tersebut merupakan hal yang lazim. Namun ketentuan tersebut dapat membuka kemungkinan dilakukannya rekayasa demi kepentingan debitor sendiri. Kemungkinan dilakukannya rekayasa tersebut diantaranya adalah debitor membuat hutang lebih dari satu dengan maksud untuk tidak membayar dan setelah itu mengajukan permohonan untuk dinyatakan pailit. Selain itu kepailitan diajukan oleh teman baik debitor yang berkolusi dengan orang atau badan hukum agar dinyatakan pailit. Permohonan semacam ini bertujuan untuk menghindarkan agar kreditor lain tidak dapat mengajukan permohonan pernyataan pailit terhadap debitor itu, setidaknya kreditor yang lain akan terhambat.

Rekayasa yang dibuat untuk kepentingan debitor dapat merugikan kepentingan kreditor dan dapat dipastikan hak-hak sebagai kreditor tidak terlindungi terhadap debitor yang mempunya iitikad tidak baik. Hal ini serupa terjadi pada kasus kepailitan antara kreditor PT. SPE, yaitu Bank CIMB Niaga melawan PT. Sumatera Persada Energi sebagai debitor. Selama menjalankan perusahaan PT. SPE tidak hanya berhutang pada satu kreditor saja yaitu PT. Bank CIMB Niaga tetapi pada kreditor lainnya yaitu PT. Panca Brothers Swakarsa, PT. Yeon San Embrioders dan lain sebagainya. Pada kenyataanya hutang beserta bunga yang harus dibayar tersebut melebihi aset-aset perusahaan PT. SPE.

Pada tanggal 4 Agustus 2014 dalam Rapat Umum Pemegang Saham PT. SPE Sukses telah dicapai kesepakatan untuk mengajukan permohonan pailit pada Pengadilan Niaga Jakarta Pusat karena perusahaan sudah tidak dapat lagi menjalankan perusahaan dikarenakan menanggung hutang yang besar. Dengan adanya kesepakatan permohonan pailit dalam rapat tersebut dinilai pihak kreditor sebagai wanprestasi debitor dan tidak adanya itikad untuk berusaha menyelamatkan perusahaan. Pada 
akhirnya Pengadilan Niaga Jakarta Pusat memutuskan mengabulkan permohonan pailit PT. SPE untuk mempailitkan diri sendiri berdasarkan bukti-bukti yang ada dan sesuai Undang-Undang 
Kepailitan PT. SPE mempunyai hutang pada kreditor dan dapat ditagih setelah jatuh tempo. Masalah yang terjadi disini adalah bagaimana perlindungan hukum terhadap kreditor dan penyelesaian hukum dalam kasus yang telah dikemukakan diatas dimana debitor mempailitkan dirinya sendiri.

Undang-Undang Kepailitan harus memberikan perlindungan yang seimbang antara kreditor dan debitor. Undang-Undang Kepailitan diadakan untuk memberikan manfaat dan perlindungan kepada kreditor apabila debitor tidak membayar utangnya, dengan adanya Undang-Undang ini diharapkan kreditor dapat memperoleh kepastian terhadap harta kekayaan dari debitor yang dinyatakan pailit karena tidak mampu membayar utangnya.

Persyaratan permohonan kepailitan salah satunya adalah dapat diajukan oleh debitor. Debitor dapat mengajukan permohonan pailit apabila mempunyai dua atau lebih kreditor yang tidak dapat menjalankan kewajibanya yaitu membayar hutang beserta bunganya yang telah jatuh tempo dan dapat ditagih. Pengadilan Niaga harus mengabulkan apabila terdapat fakta yang sesuai dengan syarat-syarat untuk dinyatakan pailit telah terpenuhi oleh pihak yang mengajukan pailit. sesuai dengan Pasal 2 ayat (1) UUKPKPU. Penulis akan mencoba memaparkan putusan badan peradilan yang terkait dengan permohonan pailit yang diajukan oleh debitor dan kaitannya dengan perlindungan terhadap kreditor.

Sesudah putusan kasasi Mahkamah Agung Nomor 227K/N/2014 yang telah berkekuatan hukum tetap tanggal 07 Desember 2014 diberitahukan kepada pemohon kasasi tanggal 14 Desember 2014 kemudian oleh PT. Bank CIMB Niaga diajukan permohonan peninjauan kembali secara lisan di kepaniteraan pengadilan niaga Jakarta Pusat pada tanggal 09 Januari 2015 disertai memori yang memuat alasan-alasan permohonannya yang diterima pada hari itu juga.

Tentang permohonan peninjauan kembali telah diberitahukan kepada pihak lawan dengan seksama pada tanggal 10 Januari 2015, kemudian terhadapnya oleh pihak lawan telah diajukan jawaban yang diterima di kepaniteraan pengadilan niaga Jakarta Pusat pada tanggal 07 Februari 2015. Permohonan peninjauan kembali yang diajukan pemohon peninjauan kembali PT. Bank CIMB Niaga yang diwakili oleh Jos Luhukay (Presiden Direktur) dan Tjindrasa Ng (Direktur), dan dalam perkaraini memberi kuasa kepada Metha Rachmawati, S.H. dan Moh Septianto, S.H., keduanya karyawan PT. Bank CIMB Niaga. Menurut Pasal 5 Undang-Undang Nomor 4 tahun 1998, permohonan peninjauan kembali harus diajukan oleh penasihat hukum yang memiliki izin praktek.

Oleh karena permohonan peninjauan kembali yang diajukan oleh pemohon peninjauan kembali tidak memenuhi ketentuan Pasal 5 Undang-Undang Nomor 4 tahun 1998, maka permohonan peninjauan kembali tersebut tidak dapat diterima. Hal tersebut juga diatur dalam UUKPKPU Pasal 7 juncto Pasal 14. Permohonan peninjauan kembali yang diajukan pemohon peninjauan kembali dinyatakan tidak dapat diterima maka pemohon peninjauan kembali harus dihukum untuk membayar biaya perkara dalam pemeriksaan peninjauan kembali ini. Demikian diputuskan dalam rapat permusyawaratan Mahkamah Agung pada tanggal 28 Juni 2015 dalam sidang yang terbuka untuk umum, dengan tidak dihadiri oleh kedua belah pihak. 
Syarat-syarat permohonan kepailitan yang diajukan PT.Sumatera Persada Energi selaku pemohon pailit sudah sesuai dengan syarat-syarat yang ditetapkan oleh Peraturan Kepailitan dalam Undang-Undang Kepailitan. Dalam Undang-Undang Nomor 4 Tahun 1998 Pasal 6ayat (3) telah ditetapkan bahwa permohonan pailit harus dikabulkan oleh pengadilan apabila secara sederhana telah terbukti bahwa persyaratan pailit menurut Pasal 1 ayat (1) telah dipenuhi oleh pihak yang mengajukan permohonan pailit, hal ini juga dijelaskan dalam peraturan kepailitan yang baru yaitu UUKPKPU Pasal 8 ayat (4).

Selanjutnya perrmohonan pernyataan pailit yang diajukan PT. Sumatera Persada Energi selaku debitor yang berbentuk perseroan terbatas, permohonan tersebut harus diajukan dengan memenuhi ketentuan Pasal 104 Undang-Undang Nomor 40 Tahun 2007 Tentang PerseroanTerbatas. Menurut Pasal 104 tersebut : “ Direksi tidak berwenang mengajukan permohonan pernyataan pailitatas perseroan sendiri kepada pengadilan niaga sebelum memperoleh persetujuan RUPS, dengan tidak mengurangi ketentuan sebagaimana diatur dalam Undang-Undang tentang kepailitan dan penundaan kewajiban pembayaran utang ”. Selanjutnya ketentuan lain dalam Pasal 89 ayat (1) Undang-Undang Nomor 40 Tahun 2007 dapat diketahui pula bahwa permohonan pernyataan pailit atas perseroan terbatas hanya berdasarkan persetujuan RUPS. ${ }^{14}$

Pembuktian tentang terpenuhinya syarat-syarat kepailitan oleh pemohon pailit ini terlepas dari pembuktian akan adanya persangkaan akan rekayasa yang dilakukan oleh debitor sebagai pemohon pailit. Hal ini bertentangan dengan kompetensi Pengadilan pada umumnya dan Pengadilan Niaga khususnya. Persangkaan akan adanya rekayasa tersebut harus dibuktikan dengan mengajukan gugatan melalui Pengadilan Negeri, yaitu Pengadilan umum yang memutus dan memeriksa perkara perdata maupun pidana sipil untuk semua golongan penduduk, sedangkan Pengadilan Niaga hanya khusus menangani masalah-masalah kepailitan yang pokok-pokok saja.

\section{B. Penyelesaian Harta Pailit Debitor Kepada Para Kreditor Sehubungan Dengan Permohonan Pailit Oleh Debitor}

Peraturan kepailitan yang ada di Indonesia masih banyak mempunyai kekurangan-kekurangan, khususnya yang berkaitan dengan pengajuan kepailitan yang dilakukan oleh debitor sendiri. Hal ini ternyata menimbulkan akibat yang merugikan di pihak kreditor, sebagai lembaga penyokong dana bagi perusahaan yang pailit tersebut. Kelemahan-kelemahan yang terdapat dalam peraturan kepailitan di Indonesia tersebut akan disalahgunakan oleh pihak-pihak yang tidak bertanggung jawab. Menurut analisis penulis, kelemahan tersebut sebenarnya bersumber dari syarat-syarat kepailitan yang memiliki batas penafsiran yang kurang jelas. 
14 Putusan Nomor 227 PK / N / 2014 / Pn.Niaga.Jkt.Pst ( diakses dari: http: // Www. Putusan. Net. / pada hari Selasa, tanggal 09 September 2017, pukul 21.00 WIB ). 
Masalah tersebut terlihat dari tidak adanya perumusan yang jelas terhadap keadaan berhenti membayar dari pihak debitor, dimana tidak ada perumusan yang jelas apakah keadan tersebut hanya sebagai akibat dari tidak dapat atau tidak mau membayar, sebab hal ini akan berpengaruh pada itikad seseorang untuk melunasi hutangnya. Hal tersebut dapat dilihat dari kasus pailitnya PT.Sumatera Persada Energi, dimana alasan PT.Sumatera Persada Energi untuk mempailitkan dirinya sendiri, karena mereka dalam keadaan tak mampu membayar dengan diperkuat oleh bukti-bukti yang berasal dari Akuntan Publik Ernst \&Young, Prasetio, Sarwoko dan Sandjaja yang menjelaskan bahwa pemohon pailit telah mengalami defisit atau kerugian yang meningkat dari tahun ke tahun yaitu pada tahun 2001 sebesar Rp.72.453.365.551,- dan dan pada tahun 2002 keerugian tersebut meningkat sebesar Rp.105.108.460.889,- dan berdasarkan laporan keuangan internal untuk tahun 2013, pemohon pailit telah mengalami defisit sebesar Rp.109.095.125.160,-.

Bukti tersebut memang telah menjelaskan bahwa memang benar PT.Sumatera Persada Energi berada dalam keadaan tak mampu bayar, tetapi kenyataan yang ada membuktikan bahwa PT.Sumatera Persada Energi belum pernah sekalipun membayar hutang-hutangnya terhadapkreditor, seperti halnya hutang yang berupa perjanjian kredit terhadap PT.Bank CIMB Niaga yang telah jatuh tempo sejak tahun 2002. Hal ini sudah membuktikan bahwa PT.Sumatera Persada Energi tidak mempunyai niat atau itikad baik untuk membayar hutang-hutangnya kepada kreditor, karena belum pernah sekalipun PT.Sumatera Persada Energi membayar cicilan hutang kepada kreditor sejak tahun 2002, padahal telah diketahui bahwa keadaan keuangan PT.Sumatera Persada Energi mulai defisit sejak tahun 2010 sedangkan pada tahun-tahun sebelumnya PT.Sumatera Persada Energi tidak berusaha untuk mengembalikan hutangnya.

Masalah yang timbul dalam kasus PT.Sumatera Persada Energi di dalam Undang-Undang Nomor 4 Tahun 1998 tidak terdapat batasan tentang hutang yang jelas, tetapi di dalam UUKPKPU telah terdapat batasan tentang hutang yang merupakan kewajiban yang dinyatakan atau dapat dinyatakan dalam jumlah uang baik dalam mata uang Indonesia maupun mata uang asing, baik secara langsung maupun kontinjen, yang timbul karena perjanjian atau undang-undang dan yang wajib dipenuhi oleh debitur dan bila tidak dipenuhi memberi hak kepada kreditor untuk mendapat pemenuhannya dari harta kekayaan debitor. Jika demikian alasan PT.Sumatera Persada Energi yang mengatakan bahwa kerugian perusahaan yang disebabkan karena penurunan nilai mata uang Rupiah terhadap Dollar Amerika adalah hal yang mengada-ada, karena hal tersebut merupakan resiko yang harus ditanggung oleh perusahan, dimana penurunan nilai mata uang tersebut pasti diikuti oleh kenaikan harga produk yang diproduksi oleh PT.Sumatera Persada Energi.

Fakta-fakta didalam kasus kepailitan PT. Sumatera Persada Energi menunjukkan bahwa keseluruhan harta debitor tidak mencukupi untuk membayar keseluruhan hutang kepada kreditor, dimana total harta debitor sebesar Rp.15.347.625.877,-- dan dalam bentuk Dollar sebesar USD 
16.184.720,13 dengan melihat fakta-fakta yang ada dapat dipastikan bahwa hutang debitor tidak dapat dikembalikan secara utuh yang berakibat merugikan kreditor secara keseluruhan, karena hal ini sangat 
jauh dari rasa keadilan. Hal ini bertentangan dengan Kitab Undang-Undang Hukum Perdata Pasal 1131, yaitu : "Segala harta kekayaan debitor, baik yang bergerak maupun tidak bergerak, baik yang sudah ada maupun yang baru akan ada dikemudian hari, menjadi jaminan untuk segala perikatan debitor".

Pasal 1131 Kitab Undang-Undang Hukum Perdata menentukan bahwa harta kekayaan debitor pailit tidak hanya sekedar untuk menjamin kewajiban untuk melunasi hutang kepada kreditor, tetapi juga untuk menjamin segala kewajiban yang timbul dari adanya perikatan. Kaitannya dengan hal tersebut, maka di dalam Kitab Undang-Undang Hukum Perdata Pasal 1233 menentukan bahwa tiaptiap perikatan dilahirkan baik karena persetujuan, baik karena Undang-Undang. Hal ini menjelaskan bahwa suatu perikatan yang dilakukanantara debitor dan kreditor lahir karena adanya perjanjian antara kreditor dan debitor yang akan menimbulkan hak dan kewajiban antar kedua belah pihak. Hak dan kewajiban kedua belah pihak tersebutakan menimbulkan suatu akibat sebagaimana diatur dalam Kitab Undang-Undang Hukum Perdata Pasal 1234 yang menyatakan tiap-tiap perikatan adalah untuk memberikan sesuatu, untuk berbuat sesuatu, atau untuk tidak berbuat sesuatu.

Berdasarkan fakta-fakta yang ada, debitor mempunyai hutang kepada kreditor yang telah jatuh tempo sejak tahun tanggal 27 Juni 2002 sampai dengan 15 Oktober 2008, sedangkan perusahaan mulai defisit sejak tahun 2010. Hal ini sudah cukup membuktikan bahwa debitor tidak mempunyai itikad baik dalam rangka pengembalian hutang kepada kreditor, karena debitor tidak berusaha mengembalikan hutang kreditor dalam jangka waktu tahun 2008-2010 sedikitpun, dimana pada waktu itu perusahaan masih belum mengalami kerugian.

\section{PENUTUP}

\section{A. Simpulan}

1. Perlindungan hukum kreditor atas kepailitan yang diajukan debitor atas permohonan kepailitan yang dilakukan oleh PT.Sumatera Persada Energi telahsesuai dengan Undang-Undang Kepailitan yang berlaku baik Undang-Undang Nomor 4 Tahun 1998 maupun UUKPKPU, karena secara substansial tidak ada perubahan dalam syarat-syarat pengajuan permohonan kepailitan. Pada kenyataannya, syarat-syarat tersebut belum representatif dalam melindungi hak-hak kreditor pada umumnya. Hal ini dapat dilihat dari tidak adanya permohonan debitor untuk meminta persetujuan kepada kreditor mayoritas dalam hal debitor mengajukan permohonan kepailitan ke Pengadilan Niaga. Syarat-syarat pengajuan permohonan kepailitan tersebut jauh dari asas keadilan bagi penyelesaian kepailitan antara debitor dan kreditor, terutama bagi kreditor yang mempunyai debitor harta kekayaannya (boedel) tidak cukup untuk membayar keseluruhan hutang kepada kreditor. 
2. Penyelesaian harta pailit debitor kepada para kreditor sehubungan dengan permohonan pailit oleh debitor, yaitu sesuai dengan peraturan kepailitan di Indonesia adalah Undang-Undang Nomor 4 Tahun 1998 yang kemudian diperbaharui menjadi Undang-Undang Nomor 37 Tahun 
2004 tentang KPKPU ternyata belum sepenuhnya lengkap untuk dapat melindungi hak-hak kreditor, tetapi justru menimbulkan masalah-masalah yang berupa ketidakjelasan akan suatu hal baik yang menyangkut tentang penafsiran maupun penyelesaian tentang kepailitan itu sendiri. Salah satu hal yang berhubungan dengan kasus PT.Sumatera Persada Energi adalah tidak ada kejelasan tentang pengembalian hutang secara penuh bagi kreditor terhadap harta kekayaan debitor pailit yang tidak cukup untuk membayar seluruh hutang-hutangnya,dimana secara tidak langsung kreditor diharuskan untuk menerima kenyataan bahwa semua hutangnya tidak dapat dilunasi secara penuh oleh debitor pailit tanpa ada tindakan-tindakan dan solusi yang dapat dilakukan oleh kreditor sebelum permohonan kepailitan tersebut diajukan debitor pailit ke Pengadilan Niaga.

\section{B. Saran}

1. Peraturan kepailitan di Indonesia, sebaiknya memuat ketentuan yang mengatur bahwa dalam hal salah satu pihak mengajukan permohonan kepailitan ke Pengadilan Niaga diharuskan untuk meminta persetujuan atau atas sepengetahuan pihak yang lain. Hal ini dimaksudkan agar antara pihak debitor dan kreditor terjalin komunikasi, sehingga dapat menemukan jalan keluar yang lebih baik sebelum masalah kepailitan ini diajukan ke Pengadilan Niaga.

2. Di dalam peraturan kepailitan di Indonesia hendaknya memuat peraturan yang khusus tentang masalah kepailitan dari Kitab Undang-Undang Hukum Perdata untuk lebih melindungi para pihak yang dirugikan, karena pada dasarnya masalah-masalah kepailitan berawal mula dari suatu perjanjian yang telah disetujui oleh kedua belah pihak, yaitu debitor dan kreditor, sehingga secara otomatis akan menimbulkan hak dan kewajiban antara keduanya. Hak dan kewajiban tersebut apabila tidak dipenuhi secara sempurna akan menimbulkan ketidakseimbangan yang berakibat pada kerugian salah satu pihak.

\section{DAFTAR PUSTAKA}

\section{Buku-Buku}

Asikin, Zainal. Hukum Kepailitan dan Penundaan Pembayaran di Indonesia, Jakarta : PT. Raja Grafindo Persada, 2010.

Prodojhamidjojo, Martiman. Proses Kepailitan Menurut Peraturan Pemerintah Pengganti UndangUndang Nomor 1 Tahun 1998 Tentang Perubahan Atas Undang-Undang Tentang Kepailitan. Jakarta : CV. Mandar Maju, 2009.

Sjahdeini, Sutan Remy, Hukum Kepailitan Memahami Faillissementsverordening Juncto UndangUndang Nomor 4 Tahun 1998, Jakarta : Pustaka Grafiti, 2012.

Soekanto Soerjono dan Sri Mamudji. Penelitian Hukum Normatif Suatu Tujuan Singkat, Jakarta : Raja Grafindo Persada, 2007. 
8516

Sutantio, Retnowulan. Kapita Selekta Hukum Ekonomi Dan Perbankan, Ctk. Pertama, Jakarta : Varia Yustisia, 2007.

\section{Makalah}

Hartono, Siti Soemarti. Pengantar Hukum Kepailitan dan Penundaan Pembayaran, Jakarta : Seksi

Hukum Dagang Fakultas Hukum Universitas Gadjah Mada, 2013.

Indaryati, Poppy. Diskriminasi Kurator di dalam Kepailitan, Semarang : Tesis Hukum dan Teknologi Program Pasca Sarjana Undip.

\section{Website}

Budisastra, Aspek Hukum Dalam Kepailitan, ( http : // budisastra. Info / home, 2009 / baca / pdf /, diunduh 30 Mei 2016 ).

Luhut M.P Pangaribuan, Hukum Kepailitan Dengan Hantu-Hantu, ( http : // majalah. Tempo interaktif. com, 08 September 2003 ), diunduh pada 3 Januari 2011.

Putusan Nomor 227 PK / N / 2014 / Pn.Niaga.Jkt.Pst ( diakses dari: http: // Www. Putusan. Net. I

pada hari Selasa, tanggal 09 September 2017, pukul 21.00 WIB ).

\section{Undang-Undang}

Undang-Undang Nomor 37 Tahun 2004 Tentang Kepailitan Dan Penundaan Kewajiban Pembayaran

Utang. 